\title{
ELOGIO DO INACABADO: DA FENOMENOLOGIA À FILOSOFIA DA ALTERIDADE
}

\section{UNFINISHED OF THE CHEER: FRON PHENOMENOLOGY TO A PHILOSOPHY OF ALTERITY}

Nilo Ribeiro Junior *

\section{RESUMO}

$\mathrm{O}$ artigo visa a debruçar-se sobre a Existência humana pensada à luz do impacto e o alcance da viragem fenômeno-ontológica da filosofia praticada por Husserl e Heidegger, embora o pensamento desses autores apareça de modo evocativo e implícito em nossa reflexão. A ênfase fica por conta da associação entre o caráter ético-poético da vida e os novos rumos que a fenomenologia tem assumido nas últimas décadas, sobretudo tendo presente a fecundidade do pensamento dos filósofos franceses como Emmanuel Lévinas, Michel Henry, Jean-Luc Marion e Jean-Luc Nancy. Trata-se de propor uma interface entre a maneira como o sentido da ação humana aparece atado à existência vivida que segundo o pensamento encarnado, não dissocia da experiência do corpo e da carnalidade originárias como lugar da transcendência.

PALAVRAS CHAVE: Fenomenologia. Existência. Ética. Poética. Carne e corpo.

\begin{abstract}
This article focuses on Human Existence in the light of Husserl's and Heidegger's phenomenologic-ontological turn, although the philosophy of these authors are not explicitly treated here. Phenomenology has treaded along new paths in the last decades, and in authors such as Emmanuel Levinas, Michel Henry, Jean-Luc Marion and Jean-Luc Nancy, its association with ethics and poetics becomes even closer. This article suggests that the meaning of human action and "life as existence" (Erlebnis in German) lived in incarnate thinking cannot be dissociated from bodily experience and flesh itself as the originary locale of transcendence.
\end{abstract}

KEYWORDS: Phenomenology. Existence. Ethics. Poetics. Body and flesh.

\footnotetext{
* Doutor em Filosofia pela UCP - Universidade Católica de Portugal e professor do departamento de filosofia da FAJE - Faculdade Jesuíta de Filosofia e Teologia. Currículo Lattes: http://lattes.cnpq.br/8047378549590212.
} 


\section{Introdução}

A temática sobre a qual nos debruçaremos nessa reflexão tem como fio condutor a "arte de existir", sendo que nossa atenção foca-se na indagação a respeito de a condição humana poder ser "autocompreendida em seu inacabamento" desde a perspectiva de uma fenomenologia da existência (NANCY, 2002, p. 25). Em seguida, trata-se de dar um passo em direção às questões concernentes ao existir quando lançado na imediação da relação encarnada com outrem como "ética da sensibilidade" (LEVINAS, 2011, p. 95).

Trazer para o centro da reflexão a incompletude da existência supõe trilhar um caminho que se contrapõe ao que se veicula sobre o Existir a partir do senso comum ou da consciência ingênua. Por isso, logo de saída, teríamos que ressaltar que o Existir não consiste em preencher-se, realizar-se nem alcançar uma condição idílica, ao menos no sentido idealista e romântico costumeiramente associado a esses verbos.

Inicialmente porque a Existência humana não se deixa apreender como se fosse objeto ou ente manuseável a bel prazer ou que se submete ao nosso domínio como "um súdito ao seu soberano" (MERLEAU-PONTY, 1999, p. 23). Afinal, existir é da ordem da "verbalidade do ser e não um substantivo" (HEIDEGGER, 1967, p. 24). Em seguida, porque a própria experiência humana nos recorda que ao pressupor uma existência satisfeita acabaria por reduzir-se ao ideal de uma visão impassível e indolor previamente estabelecida, o que parece um ledo engano. Daí que não haja outra saída senão admitir que a Existência nos preside e nos leva por caminhos inesperados, nem sempre queridos por nós, embora por vezes nos traga novos ares e uma boa-nova jamais experimentada antes. Nesse caso, tem sentido dizer com a tradição fenomenológica de que a "existência precede a essência" (LÉVINAS, 1997, p. 210), dado o fato de o existir ser do âmbito da auto-donação (dom) ao contrapor-se à representação da consciência, como reafirma o filósofo francês Jean-Luc Marion. ${ }^{1}$

De praxe quem nos põe em contato com esse paradoxal "enigma da existência", ou com esse "avesso" que provoca um reviramento em nossas entranhas são "os Poetas e os Profetas" (LÉVINAS, 2011, p. 31). Contando, pois, com o fato de que somos acompanhados por alguns deles, ousaria evocar suas palavras de modo que elas venham a ressoar qual uma

\footnotetext{
${ }^{1}$ Cf. MARION, J-C. O Visível e o revelado. São Paulo: Loyola, 2010. Ao referir-se ao caráter saturado do fenômeno pretende associá-lo ao pensamento daquilo "que se doa" à consciência. Sua intenção é de salientar que essa donação no fenômeno extravasa a consciência ao mesmo tempo em que assegura a originalidade da consciência na experiência e abandona a representação do vivido pela consciência (MARION, 2010, p. 74).
} 
interpelação radical para nossos sentidos. Talvez tivéssemos que repeti-los a fim de não nos acostumarmos com as falsas seguranças que alguns "estilos de vida" pretendem inculcar em nossa "cultura da saciedade a todo custo" (ROUDINESCO, 2008, p. 45). Ora, "viver é muito perigoso", ou melhor, "a vida só é possível reinventada", assim, gostam de dizer e redizer de inúmeras maneiras e em diversas circunstâncias Guimarães Rosa e Cecília Meireles. Gostaria, no entanto, de evocar um verso de Fernando Pessoa, que pode provocar espanto ou suscitar um trauma naquele cuja existência se vê retratada no poema.

\footnotetext{
Não sei se a vida é pouco ou demais para mim. Não sei se sinto de mais ou de menos. Não sei se me falta escrúpulo espiritual, ponto de apoio na inteligência, consanguinidade com mistério das coisas, choque aos contatos, sangue sob golpes, estremeção aos ruídos. Ou se há outra significação para isto mais cômoda e feliz (PESSOA, 2011, p. 104).
}

Nesse caso, parece sugerir o poeta que o existir é bem o contrário de Ek-sistir: é um constante des-sistir de si mesmo, um desnudar-se frente à "vida que nos invade com a força de um abraço" (HENRY, 2004a, p. 46). Eis, pois, a indagação que surge nesse contexto: se os poetas devem ser considerados desvairados e anárquicos enquanto nós, ao contrário, vivemos à procura de lucidez e por isso nos opomos às supostas seduções veiculadas por eles, ao rechaçarmos ter de viver sob a égide da incerteza ou da insegurança. A questão insiste e não pode ser descartada sem mais. Trata-se de saber se a Poética não se revela como maneira de um "Dizer originário" (LÉVINAS, 2011, p. 31) daquilo que em princípio parece indizível exatamente porque o próprio existir só se desvela na andança, na partida e "se esconde quando se pretende anunciar sua chegada" (HENRY, 2004a, p. 44).

Em certo sentido os Profetas parecem cúmplices dos Poetas quando teimam em dizer aquilo que só compreendem bem depois de terem dito aos outros: a vida é um sopro e os homens não podem contar o número de seus dias. Há tempo para sofrer e para amar, para morrer e para lutar, para partir e para ficar. Ora, tanto os Profetas, como os Poetas, pretendem nos remeter para o fato de que a Existência tem de ser vivida como se não houvesse amanhã. Aliás, foi em vista desta insaciabilidade do Existir que o Profeta aventurou-se em dizer-nos quase num tom irônico senão mais real do que o existir: bem-aventurados os que choram, bem-aventurados os que têm fome e sede de justiça, bem-aventurados são aqueles para quem não falta a falta cotidiana porque deles é reino dos céus. É, pois, em vista de nos aproximarmos dessa verdade da Existência preconizada pelos Poetas e os Profetas, sem 
sermos acusados de entregar-nos à doxa (opinião), que pretendemos dar um passo adiante e recorrer àquilo que dizem os Filósofos.

Desde a Grécia antiga até os nossos dias constata-se que uma corrente expressiva da filosofia tem alimentado uma postura ímpar diante do existir, denominada de atitude "fenomenológica" (HUSSERL, 2008, p. 71). Atitude que se ocupa da Existência (humana) e a ela se destina. Em função disso, a fenomenologia propugna o método da "epoché" (HUSSERL, 2008, p. 51), que se ocupa da suspensão de nossas certezas, e da prática de certo "ceticismo" (HUSSERL, 2008, p. 62) em relação a tudo o que se afirma "categoricamente" sobre a Existência. Consequentemente, é posta em questão a "atitude ingênua", seja ela letrada ou não, mas que pensa tudo saber sobre a vida. Daí a urgência de se ter de "colocar entre parênteses" ou de "suspender o juízo" e pôr à prova os pressupostos tidos como preconceitos e preconcepções que impedem a Existência de se mostrar em sua "facticidade" ou em sua concretude na temporalidade (HEIDEGGER, 1967, p. 48). Ora, a "atitude ingênua" também compromete a estética do existir, cujo acesso autêntico brota somente da originalidade do "aparecer originário no mundo da vida" (HUSSERL, 2008, p. 89).

$\mathrm{Na}$ perspectiva fenomenológica, emergem algumas convicções a respeito do existir sem as quais incorreríamos em equívocos a respeito da significação da vida e a uma espécie de autoengano com relação à nossa própria maneira de existir. Poderíamos correr o risco de viver embalados pela "representação da Existência", atraídos por um saber ex-tático ou um “conhecimento que prescinde da sabedoria imanente da própria vida" (HENRY, 2003, p. 45).

\section{A existência humana como evento}

Ao considerar a vida no infinitivo (Existir) ou no gerúndio (Existência), o que a epoché pretende nos recordar é que a Existência não é um lugar cômodo, estático, submetido a um pensamento ou a um sujeito absoluto que pensa tudo poder sobre ela. A Existência também não se subjuga a um Espírito a quem são dadas a priori as "condições de possibilidade" de seu Existir, de modo a preencher-se de coisas, de pessoas, de sociedade e de Deus num movimento transcendental que vai para fora, e em seguida, faz o caminho de regresso a si mesmo e se autoerige como fonte de todo saber, representado de maneira plástica por "Ulisses, o grande herói da Odisseia" (LÉVINAS, 1997, p. 231).

Não há, pois, lugar para um Existir que prescinda de sua subjetividade absoluta, isto é, que se distancie de sua "materialidade viva, de sua própria imanência, da vida da 
sensibilidade que antecede todo pensamento e toda reflexividade" (HENRY, 2003, p. 67). Por isso a Existência é do regime do que os gregos denominam de Kairós. A saber, um evento habitado pela temporalidade feita de chances de Existir a partir da própria vida. Isso significa que não somos meros expectadores, ou "sujeito de sobrevoo", que depois de lançar um olhar theo-rético sobre a existência pode dedicar-se à "arte da transformação" em vista de realizar aquilo que já é, previamente, “conhecido e querido pelo Espírito” (LÉVINAS, 1997a, p. 236).

Em oposição à primeira postura, a Fenomenologia também nos recorda que não somos “arqueólogos". Contrariamente à arte da contemplação, não se trata de viver de vasculhar os rudimentos ou os fósseis da Existência auxiliados pela "eficácia de um saber empírico-formal, como se ele nos oferecesse o único e verdadeiro acesso ao sentido da Existência" (HENRY, 2012, p. 71). Nessa esteira, apesar de seu valor irrefutável, tanto o saber investigativo das ciências humanas como o saber das ciências da natureza correm o risco de restringir o acesso à Existência, limitando-o ao viabilizado pela "arte da escavação" (NANCY, 2002, p. 29). Afinal, esta se mune do poderoso instrumental de meios/fins que, por sua vez, segue a lógica da causa-efeito, pela qual "a Existência se reduz ao empiricamente verificável e previsível" (HENRY, 2003, p. 59).

Ora, a fenomenologia teima em dizer sobre a impossibilidade de se praticar uma espécie de "devassa na intimidade da Existência" com o intuito de controlá-la e, assim, de prevenir todo tipo de incerteza e mal-estar porventura dela decorrentes. Contra esse movimento, Lévinas insurge de maneira quase profética ao dizer que "o anti-herói Jonas, sem poder retirar-se de sua Existência, se sente lançado ao mar cujas ondas batem por todos os lados sobre seu frágil barquinho" (LÉVINAS, 1998, p.75). Nesse caso, não lhe resta, diante do fracasso de sua fuga, senão dormir no porão da humanidade embalado pelo sono (ou sonho) de um dia, quem sabe, se tornar um exímio escafandrista.

Nas entrelinhas o autor visa enfatizar a premência de se ter de Existir a fim de poder inventar novas possibilidades para a Existência. Poderíamos acrescentar que faz parte da "condição humana" essa travessia ingênita sem possibilidade alguma de distanciamento do rio no qual estamos imersos graças à "força de outrem", que lançando-nos ao mergulho, nos espera no "aqui dentro" mesmo do próprio Existir (LÉVINAS, 1998, p. 111). Só na travessia é descortinada para nós uma margem que, por ser sempre uma "terceira" margem, ausenta-se do campo da visão, do alcance de nossas mãos e da força da Razão e da Técnica. Nesse caso, o velho adágio português só tem significância existencial para o navegante que se sabe inconcebível sem o mar. E por isso pode bradar com a força do peito: "navegar é preciso, 
viver não é preciso". Do contrário a existência se reduziria a arquitetar e construir naus sem jamais correr o risco de se lançar na aventura da precariedade de ter-se de viver a nado.

\section{A existência vivida e arte dos contrários}

Outro ponto sobre o qual insistem os filósofos da epoché é que o Existir é sempre presidido por um Sentir primitivo, isto é, pelo fruir e pelo padecer sincronicamente vividos graças ao "Páthos da vida" (HENRY, 2003, p. 142). Portanto, existir é sempre do âmbito dos estados vividos antes de serem pensados; dos sentidos à flor da pele, isto é, da ordem da alegria e da tristeza, da angústia e do entusiasmo, da fome e da saciedade, da fruição e da precariedade, do medo e da coragem, dos encontros e dos desencontros. Em suma, a Existência é vivida segundo a "arte dos contrários", sem deixar-se capturar pelas sínteses ou ser seduzida pelas totalidades. Assim, essa maneira de perceber a Existência evoca uma Sabedoria - saber que nasce da existência e não da essência - que se contrapõe à lógica dos projetos mirabolantes e das projeções ensandecidas, cuja finalidade é o tão propalado sonho do repouso, da tranquilidade, da harmonia segundo a ataraxia dos estoicos ou dos epicuristas. $^{2}$

Em oposição a esse "combate ostensivo" contra as paixões, os Poetas e os Profetas insistem que é próprio da "condição humana" ser habitada por um inquietante paradoxo ou uma multiplicidade de contrários sem que isso a enfeie, a empalideça, a deprecie ou a diminua, e sem que, por isso, a Existência tenha de ser exorcizada da "densidade" de seu Existir. Pelo contrário, consideram que a dignidade do Existir emerge exatamente dessa espécie de "fraqueza consubstancial à sua materialidade" (NANCY, 2000, p. 21). São, pois, esses contrários que, sem serem expurgados da Existência, apontam para sua "remissão, sua verdade nua e crua, enfim, sua bondade" (NANCY, 2000, p. 5). Dessa mesma condição contraditória aos olhos dos Sábios, brota uma sabedoria que consiste em plasmar a vida afundando-se nela e não dissolvendo seus contrários. Graças a eles, se "manifesta a beleza do inacabamento do Existir humano" (HENRY, 2003, p. 45).

Nesse sentido, Filósofos e Poetas mantêm certa cumplicidade com relação à maneira de lidar com o "drama da existência", solo comum que os aproxima e que lhes permite

\footnotetext{
${ }^{2}$ A ataraxia consiste na completa ausência de perturbação ou inquietação. E é alcançada através do domínio ou da extinção das paixões, dos desejos e das inclinações sensoriais. Nessa perspectiva, as sensações são indissociáveis de tudo que é fugaz, efêmero e incerto porque inconsistente e irredutível à Razão. Nesse caso, a arte da Existência consiste no ferrenho combate contra os afetos. Essa arte tem como escopo pôr ordem nas paixões por meio de um Pensamento claro e distinto, isento da impureza de que o corpo é portador.
} 
transitar de maneira nova entre o pensar e existir, de modo a poderem expressar o inacabamento da vida seja através da obra de arte, seja através do exercício do pensar. Nesse sentido, a poesia de Clarice Lispector é paradigmática, pois conjuga com maestria a arte do sentir e do dizer que brota da própria existência, vivida e encarnada.

Em seu romance "Um sopro de Vida" (LISPECTOR, 1978), a poetisa retrata a existência por meio de dois personagens denominados por ela como: “Autor" e “Ângela". De maneira inusitada, faz emergir pela boca desses dois protagonistas a condição humana marcada pelos seus contrários. Em primeiro lugar, entra em cena o personagem chamado "Autor". E ele diz de si mesmo:

\footnotetext{
Ângela é muito parecida com o meu contrário. Ter dentro de mim o contrário do que sou é em essência imprescindível: Não abro mão de minha luta e de minha indecisão e o fracasso - pois sou um grande fracassado - o fracasso me serve de base para eu Existir (LISPECTOR, 1978, p. 48).
}

Em seguida Ângela, o avesso do Autor, toma a palavra:

Eu só uso o raciocínio como anestésico. Mas para a vida sou diretamente uma perene promessa de entendimento do mundo submerso. Agora que existem computadores para quase todo tipo de procura de soluções intelectuais - volto-me para o meu rico nada interior. E grito: eu sinto, eu sofro, eu me alegro, eu me comovo. Só o meu Enigma me interessa. Mais que tudo, me busco no meu grande vazio (LISPECTOR, 1978, p. 48-49).

Que o "fracasso" sirva de base para o existir humano, isso significa ter de admitir que a materialidade mais remota da existência não se identifica com o sucesso, o êxito, mas ao contrário, trata-se de algo que é do regime de certa perda de si, de êxodo incontido no coração humano e que o impulsiona a viver do provisório. Mas está implícito ao existir humano o fato de que o fracasso não se confunde necessariamente com a resignação ou com o ressentimento. Ora, que certo movimento de des-inter-essamento, isto é, que um sair de seu si (humano) esteja na base do Existir evoca imediatamente o seu contrário, vindo da mesma base, isto é, a fecundidade do Existir, do qual advém o nada interior graças ao Enigma que inabita o ser humano.

Talvez noutra passagem a própria poetisa nos ofereça pistas para vislumbrar o alcance da "estética do inacabado" enquanto associada ao Páthos do Existir. Tomando novamente a palavra o personagem cujo nome é "Autor" nos recorda: 


\begin{abstract}
Ângela é uma curva em interminável sinuosa espiral. Eu sou reto, escrevo triangularmente e piramidalmente. Mas o que está dentro da pirâmide - o segredo intocável, o perigoso e inviolável - esse é Ângela. O que Ângela escreve pode ser lido em voz alta: suas palavras são voluptuosas e dão prazer físico. Eu sou geométrico. Ângela é espiral de finesse. Ela é intuitiva, eu sou lógico. Ela tem medo de errar no emprego das palavras. E eu não erro. Bem sei que ela é uva sumarenta e eu sou a passa. Eu sou equilibrado e sensato. Ela está liberta do equilíbrio que para ela é desnecessário. Eu sou controlado, ela não se reprime - eu sofro mais do que ela porque estou preso dentro de uma estreita grade de força da higiene mental. Sofro mais porque não digo por que sofro (LISPECTOR, 1978, p. 46).
\end{abstract}

Enfim, o existir humano tomado do ponto de vista fenomenológico, para além do caráter psicológico que poderiam evocar os personagens apresentados pela Poética, nos põe em contato com a verdade de nosso inacabamento vital. Ele consiste na "aceitação" do fracasso e na "entrega" inquieta ao desejo suscitado pela fecundidade que o segredo inaudito, perigoso e inviolável da existência nos oferece para existir. Trata-se de Existir de outro modo que na banal mesmidade da procura de univocidade de sentido e no conforto de ter de viver a tentar apaziguar, a qualquer preço, "os diversos personagens que nos habitam” (NANCY, 2002, p. 23).

\title{
4 A existência e o mal-estar da contemporaneidade
}

Tratar a Existência humana a partir do drama da facticidade como o fazem os Poetas, os Profetas e os Filósofos, talvez pudesse deflagrar alguma suspeita sobre nossa abordagem. Entretanto, vale esclarecer, admitir que a existência seja da ordem da incompletude não significa, de modo algum, que tenhamos "capitulado" diante dos pós-modernismos que insistem na “insustentável leveza do Ser” (KUNDERA, 2008) e na máxima do individualismo contemporâneo, preconizada por Milan Kundera, como uma existência líquida, indolor, performática, acelerada por sua vez pela "cultura do espetáculo que preconiza uma moral do gozo a qualquer preço". 3

É verdade. A ideologia da insustentável leveza do Ser se apresenta como uma "apologia do inacabado". Contudo, a ela se opõe a percepção dos Poetas, dos Profetas e dos Filósofos. Quando se referem ao fracasso, ao vazio e à convivência dos contrários sem sínteses e sem suprassunções, nenhum deles concebe o Existir humano como uma "mônada"

\footnotetext{
${ }^{3}$ Afirma Debord que "considerado de acordo com seus próprios termos, o espetáculo é a afirmação da aparência e a afirmação de toda vida humana - isto é, social - como simples aparência. Mas a crítica que atinge a verdade do espetáculo o descobre como a negação visível da vida; como negação da vida que se tornou visível" (DEBORD, 1997, p. 10).
} 
sem portas e janelas, isto é, sem referência a nada ou a outrem nem apostam no final do sujeito (DEBORD, 1997, p. 12).

Nesse sentido, jamais tomariam como protótipo do Existir a personagem Sabina do romance de Kundera. Ela encarna o arquétipo da leveza à medida que constrói para si uma existência solitária (KUNDERA, 2008, p. 45). Devotada à arte e extremamente sensual, Sabina manifesta seu desprezo e profunda insatisfação pelo que considera como sendo da ordem do "grotesco" que, segundo ela, à maneira de uma feiura generalizada, alastra-se pelo mundo sem cultura e sem beleza de nossa época. "Sua atração por Tomaz se justifica na medida em que este personifica precisamente o novo tipo de anti-herói dos tempos pósmodernistas" (KUNDERA, 2008, p. 47). Como Sabina, ele não se permite abraçar a existência tecida de relações no mundo. Em suma, a existência de Sabina está marcada pela experiência da insustentável leveza, horizonte incontornável a todo aquele que procura cultivar uma existência que se desata das relações cotidianas sejam elas afetivas com os próximos mais próximos, sejam elas territoriais, culturais, sociais, políticas, religiosas, etc. Dessa forma, o sujeito se destitui dos dramas das relações humanas com seus percalços e descobertas. Mas resta saber qual o preço a ser pago para se viver embalado por esse esteticismo da indiferença, sem alteridade e sem transcendência (Cf. KUNDERA, 2008, p. $65)$.

Noutra direção, ao insistir no elogio do inacabado, também nos opomos aos atualíssimos discursos dos pós-humanismos, para os quais tudo em nossa humanidade, especificamente a materialidade inexorável de nossa Existência, parece ser colocada em questão (DEBORD, 1997, p. 43). Na medida em que a nova "arte de fabricação" apregoada pela antropotécnica teima em anunciar aos quatro cantos do mundo a proeza de um novo biopoder, capaz de substituir nosso "pobre corpo mortal e obsoleto" (HENRY, 2012, p. 121), por outro absolutamente informatizado ou um corpo-protético, corre-se o risco de erigir-se uma "nova base material" para nosso Existir que acabe por desprezar e descartar a carnalidade, "o mais efetivo estofo do advir de nossa vida como corpropriação" (HENRY, 2003, p. 105).

Enfim, vale salientar que, por paradoxal que possa parecer, a essa "in-sustentável leveza do Ser" dos pós-modernismos, bem como o esvaziamento do corpo pela "arte da fabricação do super-homem" dos pós-humanismos, cada qual a seu modo, corresponde um Espiritualismo galopante que, em nossa cultura, deságua numa equivalente perda de 
densidade existencial. Nesse caso, a carne e a "encarnação" da Existência não passam de mera "necessidade a pesar sobre o Pensamento Puro" (NANCY, 2000, p. 24).

Diante da forte tendência ao neognosticismo da cultura contemporânea, somos interpelados a fazer uma inflexão que permita propugnar o elogio do inacabado em função da reabilitação da "existência corporal” (LÉVINAS, 1988, p. 147) ou a condição humana "encarnada" (MERLEAU-PONTY, 2007, p. 142). Se, em princípio, isso soa como tautológico, urge reforçar esse elo como um lugar de interrogação a duas posturas que, a um olhar desavisado, se apresentam como antagônicas. Uma primeira que rechaça terminantemente o inacabamento da Existência para se apoiar na ideia de natureza humana imutável; e uma segunda que associa à arte do inacabado a leveza do ser, já que aqui tudo é efêmero e fluido. Não é difícil ver que ambas partilham a mesma relutância em lidar com a "encarnação" de nossa humanidade, o que é indicativo do receio da "aventura humana como arte da travessia" em direção à alteridade em qualquer uma de suas faces (MERLEAUPONTY, 2007, p. 143).

\section{De outro modo de existir e a encarnação do humano}

Distanciando-se tanto das tendências extáticas do pós-modernismo como do pensamento essencialista, trata-se de evocar, ainda que brevemente, algumas intuições fundamentais da Filosofia da encarnação, indicativas do esforço de reabilitação da carnalidade como maneira originária do Existir.

Destaca-se, nesse cenário, o pensamento de Simone Weil que, referindo-se à Existência humana, a associa, de imediato, à "gravidade e a graça" (WEIL,1993, p. 5). Desse modo, o inacabamento da Existência decorre da densidade da carne, a ponto de a sabedoria da vida circunscrever-se ao "corpo conquanto é o lugar privilegiado da graça" (WEIL, 1993, p. 22). Isso, porém, não porque "a graça venha em socorro do corpo", mas ao contrário, porque o corpo é de carne (sensibilidade) e por isso "agraciado em seu estado originário" (WEIL, 1993, p.25).

A carnalidade que nos habita é a "matéria impressiva patética" da Existência (HENRY, 2003, p. 69), cuja vida consiste simplesmente em Sentir, enfim, encarnar-se graças à Sensibilidade ou ao "Páthos que habita nosso corpo" (HENRY, 2003, p. 173). E a maneira dessa vida encarnada consiste em acolher passivamente a graça dessa imanência da carne da qual não podemos nos distanciar a não ser pela desventura de um pensamento que se 
desvencilhe e se queira impor-se à "carnalidade humana com a intenção de lhe conferir o sentido que ela não possuiria por si mesma" (HENRY, 2003, p. 174). Por isso tem razão Simone Weil quando ressalta que a graça só é graciosa, criativa, por conta da gravidade terna e tenra de nossa carne, sem a qual o "espírito encarnado" não passaria de uma invenção da gnose. Fazer-se carne é inventar-se continuamente "nesse movimento de vivificação da existência humana" (WEIL, 1993, p. 45).

Emmanuel Lévinas, por sua vez, propugna a intriga entre o que ele denomina de euhipostático e a alteridade de outrem. Essa relação se inscreve e se instaura no bojo do Existir humano, constituído do encontro entre um eu (moi) como Mesmidade satisfeita e a Alteridade vazia do outro. Ao enfatizar a condição humana como existência encarnada, ele nos conduz a “dois movimentos” peculiares de seu pensamento ético (LÉVINAS, 200, p. 43).

Primeiro, insiste em que, graças ao nosso corpo, nos afirmamos no ser como "hipóstase" (LÉVINAS, 2000, p. 43), isto é, como substância (nome) ou lugar do qual não podemos nos distanciar pelo fato de nos encontrarmos, desde sempre, declinados sobre ele, imersos no corpo sem poder pensá-lo antes de encarná-lo. É, pois, essa posição inegociável com o Espírito, assegurada pela própria corporeidade, que possibilita ao sujeito uma maneira especial de viver ou de poder "viver de..., isto é, viver de tudo que chega à boca, oferecido para nossa degustação e felicidade, pelo mundo dos alimentos terrestres, como mundo da fruição" (LÉVINAS, 1988, p. 114).

Da mesma forma, esse corpo único, substancial, hipóstase que goza, é também o corpo que sofre, chora, sente dor e porta em si todo tipo de padecimento. Nessa esteira, a condição primeva de nosso Existir irrompe como "sensibilidade" e afetividade primordiais (LÉVINAS, 1988, p. 120). Nela o advir da vida se sincroniza na "alegria da falta" e na "tristeza da fartura" como expressão de nosso contentamento descontente imerso na carne como sensibilidade.

Por isso, referindo-se, primeiramente, à esfera da Existência como hipóstase ou como corporeidade intransferível que somos como unicidade, o filósofo visa a expressar de maneira genial aquilo que se poderia denominar aqui de "amor da vida" (LÉVINAS, 1988, p. 129) do que nos é dado à fruição, que a encarnação se incumbe de cumprir. A encarnação, portanto, não é, em primeiro lugar, da ordem do projeto, mas da existência imediata porque não há uma ideia dada a priori do corpo que deve se encarnar. O corpo enquanto vivido e sentido "já existe como encarnação sem ter de recorrer a uma ideia de fora que o mova e o inspire" (LÉVINAS, 1988, p. 145). 
Nesse contexto, há que ressaltar a intima relação que Lévinas estabelece entre a vida como encarnação e a "obra de arte" do corpo inacabado, tendo como protótipo a escultura de Rodin.

\begin{abstract}
É bem verdade que o corpo sempre passava [nas filosofias encarnadas] por ser mais do que um acúmulo de matéria. Ele abrigava uma alma que ele tinha o poder de expressar. O corpo podia ser mais ou menos expressivo e tinha partes que o eram, mais ou menos. O rosto e os olhos, espelhos da alma, eram por excelência os órgãos da expressão. Mas o fato é que a espiritualidade do corpo não reside nesse poder de expressar o interior. Em virtude de sua posição, ele cumpre a condição de toda interioridade. Ele não expressa um evento. Ele é, ele mesmo, este evento. É uma das mais fortes impressões que se retém da escultura de Rodin. Seus seres não se acham nunca sobre uma plataforma convencional ou abstrata. $\mathrm{O}$ evento que suas estátuas realizam reside muito mais na sua relação com a base, em sua posição, do que na sua relação com uma alma - saber e pensamento - que eles teriam a expressar (LÉVINAS, 1998, p. 88-89).
\end{abstract}

Salta aos olhos o que o filósofo lituano reitera: o corpo só pode ser considerado "obra de arte" no sentido genuíno se lhe for assegurada essa "materialidade ingênita" (LÉVINAS, 1988, p. 146). Segundo ele, a carnalidade sustenta o corpo de modo que ele jamais se deixa absorver pela figura ou pela forma que tenda a "esconder" ou desprezar sua base. Em última instância, a carne revela o caráter paradoxal da condição humana, a saber, a alternância entre sua plasticidade e sua imaleabilidade irredutível às formas. E isso se justifica porque se, por um lado, a carnalidade é a sede substancial do sentir ou da sensibilidade, isto é, o lugar em que os sentidos recebem sentido, estância na qual ancoram os afetos, por outro lado, os sentimentos e as paixões humanas jamais se esgotam, nunca acabam de emergir graças a esse “movimento ininterrupto, incontido e infinito do sentir" (LÉVINAS, 1988, p. 119).

Por isso a carnalidade mostra-se avessa e relutante à univocidade do esteticismo da modernidade que reivindica para si a pretensão de "talhar" ou "moldar" aquilo que denomina de "matéria bruta que somos nós" em uma "obra acabada" e "refinada" do Espírito. Afinal, isso redundaria no esvaziamento da subjetividade viva e vivificante da "Existência encarnada sempre inacabada" (LÉVINAS, 1988, p. 150).

Entretanto, Lévinas não interrompe o pensamento do Existir em seu inacabamento em torno da hipóstase. De fato, a Existência só lhe aparece em sua irredutibilidade absoluta porque o corpo hipostático (fruição/padecimento) encontra-se imediatamente aproximado pelo "Rosto de outrem" (LÉVINAS, 1988, p. 173). Eis, que a chegada de outrem vindo de alhures crava em nós a face do "Rosto como ideia do Infinito" (LÉVINAS, 1988, p. 183). Afinal, o Rosto em sua extraterritorialidade, não se enquadra às justas medidas da autoctonia 
do eu-hipostático. A relação com outrem é da ordem do "Desejo". É, pois, o desejo que conduz a relação à “encarnação para outrem” (LÉVINAS, 1988, p. 176).

O Desejo de outrem não nos realiza nem nos plenifica porque é dado para aquele que não necessita de nada, que não carece do outro para completá-lo, pois o eu-hipostático já encontrou no mundo de sua fruição e de seu padecimento "a significação imediata de seu existir" (LÉVINAS, 2011, p. 127). Graças, portanto, a essa distância abissal que me separa do outro é possível compreender que o Desejo se ponha dentro de meu corpo-hipostático como desejo concreto de oferecer ao outro as comidas e as bebidas das quais fruo, "de arrancar o pão de minha boca e do qual ele carece mais do que eu" (LÉVINAS, 2011, p. 95).

E, para além disso, a radicalidade do Desejo nos impulsiona porque o Outro nos cinge e nos toma pela mão, para em seguida nos apontar o longo caminho a percorrer, abrindo mão de nos possuir e nos reter para ele. Depois se despede de nós e toma outra direção na encruzilhada da vida. Mas a imediação do movimento de aproximação e distanciamento provoca uma "comoção tal em nossa carnalidade que não conseguimos mais resguardar-nos" (LÉVINAS, 2011, p. 95). Saímos correndo à procura do outro a fim de nos oferecer (a nós mesmos) na "hospitalidade" (LÉVINAS, 1988, p. 154), na responsabilidade e na compaixão. Enfim, na "minha substituição ao próximo" (LÉVINAS, 2011, p. 142) e na "maternidade" (LÉVINAS, 2011, p. 95) sinto-me visceralmente exposto a acolher outrem, certo de que estando sempre de passagem, ele não tem onde recostar a cabeça.

O sensível - maternidade, vulnerabilidade, apreensão - ata o nó da incarnação numa intriga mais ampla do que a apercepção de si; intriga onde estou atado aos outros antes de estar ligado ao meu corpo (LÉVINAS, 2011, p. 95).

Ora, a carne que nos habita e que nos constitui como sensibilidade antes mesmo que sejamos pensamento nos move com tal ímpeto ao encontro de outrem que não resistimos em nos lançarmos apressadamente em viver de cuidar, de socorrer, enfim, de declinar-nos diante de seus olhos tristes e de seus pés descalços.

\section{Conclusão}

Inspirados, pois, pelo comentário de Lévinas sobre a maneira como Nietzsche concebe a obra de arte, certamente poderíamos finalizar nossa reflexão com uma provocação. De saída não se pode olvidar que em Nietzsche a obra de arte é presidida por duas forças criativas. As 
forças apolíneas (Apolo) primam pela busca da harmonia, da beleza, da simetria, das formas puras, do acabamento. As forças dionísiacas (Dionísio), ao contrário, são portadoras de uma assimetria latente, da desproporção e da descontinuidade, dando lugar à hybris ou à falta de limites de modo que esse excesso abre espaço para aquilo que há de "grotesco" na criação artística (NIETZSCHE, 2005, p. 23).

Recordando, pois, que o Existir humano se configura como arte da encarnação graças ao corpo substancial que nos constitui pela relação subsistente com outrem, ousaríamos dizer, seguindo a dinâmica do pensamento levinasiano, que a arte do inacabado privilegia as "forças dionisíacas" em detrimento das "forças apolíneas" (LÉVINAS, 1988, p. 181). Isso só se justifica porque, em última instância, a estética do Existir humano é da ordem da relação com “a nudez do Rosto de outrem” (LÉVINAS, 1988, p. 176). Esta por sua vez evoca tanto a majestade e a irredutibilidade do outro como a vulnerabilidade do Rosto enquanto ele é o pobre, a viúva, o apátrida, o peregrino, enfim, evoca aquele que sendo extraterritorial é tudo aquilo que eu não sou. Isso acentua a distância e a assimetria que a "relação subsistente" mantém entre mim e o outro (LÉVINAS, 1988, p. 181).

O Elogio do inacabado diante do Rosto não poderá, portanto, recusar-se a ser uma espécie de "arte da obliteração", isto é, uma arte de assignação (tatuagem) que se cola ao Existente, uma vez que a chegada do rosto não nos deixa impassíveis. Ela marca, fere, vinca e envelhece nosso corpo e nossa existência, destinando-a a se tornar um corpo ou um Existir "de" outrem. Na perspectiva da relação com outrem, a arte do inacabado privilegiará sempre uma dimensão do "grotesco" e do feio, não tanto pelo reconhecimento das "forças dionisíacas" que agem na esfera da criatividade artística, como queria Nietzsche, mas por conta do Desejo do outro que no contato convoca o Existente a cuidar da fragilidade extrema de seu Rosto marcado pela desfiguração, pela miserabilidade, dolência, enfim, por sua mortalidade (LÉVINAS, 1988, p. 181). Esse mesmo Rosto enquanto traço do infinito é visitação pela qual passa a transcendência na imediação da relação. Por tudo isso é possível dizer que esse elogio é consoante a um a-deus, isto é, associa-se inexoravelmente a uma “sabedoria do amor ao serviço do amor" (LÉVINAS, 2011, p. 176). 


\section{Referências}

DEBORD, Guy. A sociedade do espetáculo. Rio de Janeiro: Contraponto, 1997.

HEIDEGGER, Martin. Carta sobre o humanismo. Rio de Janeiro: Ed. Tempo Brasileiro, 1967.

HENRY, Michel. A barbárie. São Paulo: É Realizações, 2012.

HENRY, Michel. De la Phénoménologie. Tome I. Phénoménologie de la vie. Paris: PUF, 2003.

HENRY, Michel. Phénoménologie de la vie. Tome III. De l'art e du politique. Paris: PUF, 2004a.

HENRY, Michel. Phénoménologie de la vie. Tome IV. Sur l'éthique et la religion. Paris: PUF, 2004b.

HUSSERL, Edmund. A ideia da Fenomenologia. Lisboa: Edições 70, 2008

KUNDERA, Milan. A insustentável leveza do Ser. São Paulo: Companhia de bolso, 2008.

LÉVINAS, Emmanuel. De outro modo que ser ou para lá da essência. Lisboa: Centro de Filosofia da Universidade de Lisboa, 2011.

LÉVINAS, Emmanuel. Entre nós. Ensaios sobre a alteridade. Petrópolis: Vozes, 1997.

LÉVINAS, Emmanuel. Ética e Infinito. Lisboa: Edições 70, p.2000.

LÉVINAS, Emmanuel. Totalidade e Infinito. Lisboa: Edições 70, 1988.

LISPECTOR, Clarice. Um sopro de vida. São Paulo: Círculo do Livro, 1978.

MARION, Jean-Luc. O Visível e o revelado. São Paulo: Loyola, 2010.

MERLEAU-PONTY, Maurice. Fenomenologia da Percepção. São Paulo: Martins Fontes, 1999.

MERLEAU-PONTY, Maurice. O visível e o invisível. São Paulo: Perspectiva, 2007.

NANCY, Jean-Luc. Um pensamento finito. Barcelona: Anthropos Ed., 2002.

NANCY, Jean-Luc. Corpus. Lisboa: Vega, 2000. 
NIETZCHE, Friedrich. A divisão dionisíaca do mundo. E outros textos da juventude. São Paulo: Martins Fontes, 2005.

PESSOA, Fernando. Quando fui outro. Rio de Janeiro: Objetiva, 2011.

ROUDINESCO, Elisabeth. O sublime e o abjeto, In: A parte obscura de nós mesmos. Uma história dos perversos. Rio de Janeiro: Zahar, 2008, pp.1-43.

WEIL, Simone. A gravidade e a graça. São Paulo: Martins Fontes, 1993. 